\title{
Some aspects of germination in Banisteriopsis variabilis B.Gates (Malpighiaceae)
}

\author{
T. F. F. Saia ${ }^{a}$ (D), S. P. Meneghin ${ }^{a}$ (D) and R. Sebastiani ${ }^{a *}$ (D) \\ ${ }^{a}$ Centro de Ciências Agrárias, Universidade Federal de São Carlos - UFSCar, Via Anhanguera, Km 17, Pedras Preciosas, \\ CEP 13600-970, Araras, SP, Brasil \\ *e-mail: renatasebastiani2014@gmail.com
}

Received: February 26, 2019 - Accepted: September 12, 2019 - Distributed: February 28, 2021

(With 1 figure)

Malpighiaceae contains approximately 1300 species in 75 genera (Anderson, 2013). Brazil has 572 Malpighiaceae species grouped in 45 genera, occupying all Brazilian phytogeographic domains (JBRJ, 2018). Among the most numerous genera in Brazil are Byrsonima Rich. ex Kunth, Heteropterys Kunth and Banisteriopsis C.B.Rob. ex Small.

Barbosa et al. (2015) suggest the use of 12 species of Malpighiaceae in ecological restoration projects in the São Paulo state, mostly shrubs and trees belonging to the Brazilian savanna (cerrado) and the semideciduous seasonal forest. Of these, only three presented lianescent habits, Banisteriopsis adenopoda (A.Juss.) B. Gates, Heteropterys intermedia (A.Juss.) Griseb. and Mascagnia sepium (A.Juss.) Griseb. (Barbosa et al., 2015). Among the species of Malpighiaceae with wide distribution that have not yet been used in ecological restoration is Banisteriopsis variabilis B. Gates. It is a native species of the Brazilian savanna (cerrado), with a shrub or lianescent habit (JBRJ, 2018), flowers with pink petals becoming white after pollination and fruits formed by winged propagules (Figures $1 \mathrm{~A}$ and 1B).

Although they are part of the ecological process, native species of lianescent habit are rarely explored for restoration projects, since reforestation focuses more on arboreal species to the detriment of other habitats (Brancalion, 2013). According to Barbosa et al. (2015), the natural establishment of a forest follows sequential stages, involving several forms of life, and it is insufficient to perform ecological restoration only with tree species. In addition, the knowledge of processes related to propagation is fundamental to any type of action with native species (Hernandez et al., 2011). Considering the diversity of Malpighiaceae in Brazil, it is possible to observe that its use in restoration projects is still incipient and that the low production of seedlings of the representatives of this family can contribute to this fact. At the same time, the scarcity of germination studies negatively interferes with seedling production of native species of Malpighiaceae for reforestation purposes.

In view of the need to contribute to the production of seedlings of native Malpighiaceae species through propagules, preliminary germination tests using gibberellic acid (GA3), different substrates and the maintenance of the $B$. variabilis propagule wing were carried out at the Universidade Federal de São Carlos (campus Araras) between
August 2016 and July 2017. The propagules were obtained from a specimen present in a well-preserved transitional fragment between the semideciduous seasonal forest and Brazilian savanna (cerrado) of the Guarnição da Aeronáutica de Pirassununga in São Paulo state (Queiroz et al., 2017). Voucher specimens were deposited in the herbarium of the Centro de Ciências Agrárias at the Universidade Federal de São Carlos (HARA herbarium).

Branches containing the propagules were collected and kept under refrigeration until sowing. The propagules were seeded in trays for sowing in batches of 100 propagules each. Initially, the winged and wingless propagules were seeded in a substrate with pine bark (Multiplant ${ }^{\circledR}$ ) and in substrate obtained in the area of the collection of propagules. After sowing these propagules, it was observed that the propagules seeded with their wing and in pine bark substrate were the most promising. Thus, a second experiment sowing in batches of 100 propagules each was conducted using winged propagules seeded on pine bark substrate in two situations, with and without the application of GA3 in aqueous solution for each locule (where there was a propagule), was pipetted $1 \mathrm{~mL}$ of GA3 at the concentration of $500 \mathrm{mg} / \mathrm{L}$ of water, the same concentration used by Nascimento and Carvalho (2016) for Byrsonima crassifolia (L.) Kunth. These authors kept the $B$. crassifolia propagules immersed for 24 hours before sowing. When we carried out the same methodology for B. variabilis we observed germination inhibition and for this reason the experiment was redone by injecting $1 \mathrm{~mL}$ of this solution in the substrate, instead of keeping them immersed.

Preliminary results show that germination rates are higher when the wing of the propagule is maintained and GA3 is applied in the substrate, allowing more propagules to germinate in a shorter time interval. In other words, GA3 probably proved to be effective in breaking dormancy in advance of germination. Germinated seedlings in the absence of GA3 took approximately 60 days to germinate, whereas in the presence of this hormone, germination began around the fifteenth day. In relation to the substrate used, although the substrate removed from the proximal surface of the specimen where the propagules were found was effective for the process, the pine bark substrate was superior. The Multiplant ${ }^{\circledR}$ substrate is composed mainly of pine bark, sand, calcitic limestone, dolomitic 

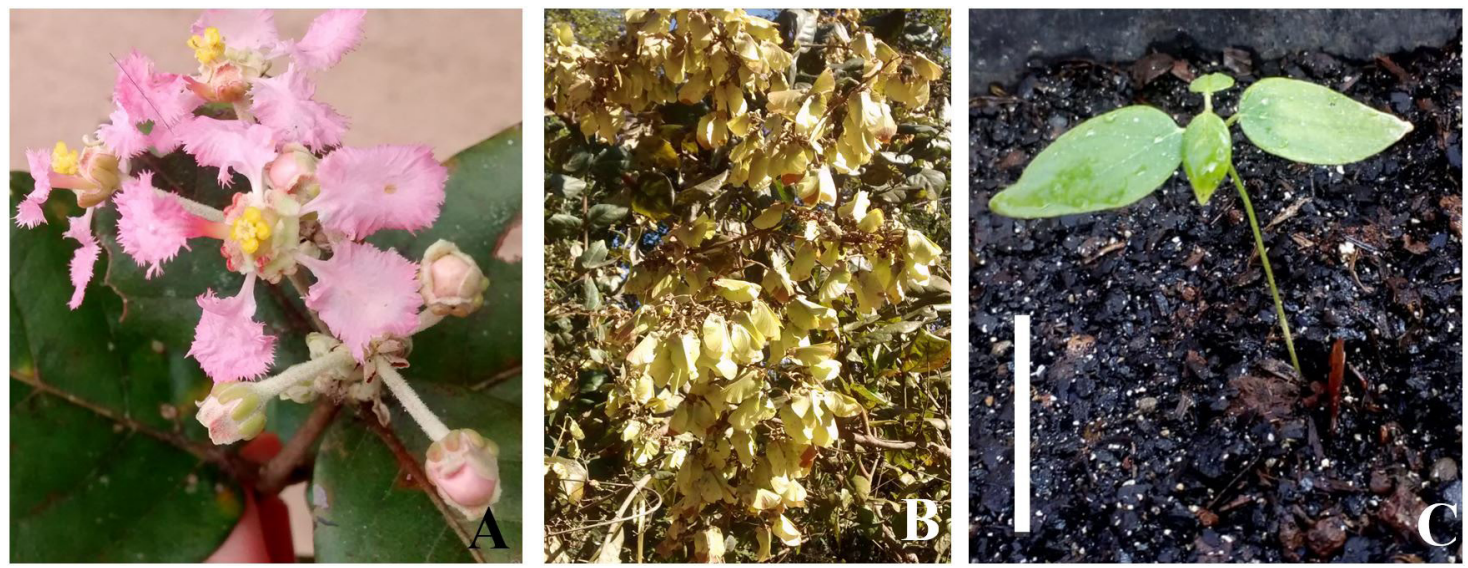

Figure 1. Banisteriopsis variabilis B.Gates. (A) Branch containing flower buds and flowers; (B) Branch containing fruits (propagules); (C) Seedling. Bar: $3 \mathrm{~cm}$.

limestone, charcoal, ammonium nitrate, ferrous sulfate and vermiculite, providing greater water retention and gas exchange. The fact that the substrate with pine bark may be more efficient may be useful for the use of $B$. variabilis in areas of reforestation that previously were used for pine cultivation.

Locardi (2011) evaluated the germination speed of B. variabilis. Seedlings, immersed in solutions of different GA4-7 concentrations, obtaining positive results at $50 \mu \mathrm{mol} / \mathrm{L}(17.3 \mathrm{mg} / \mathrm{L})$ and $100 \mu \mathrm{mol} / \mathrm{L}(34.6 \mathrm{mg} / \mathrm{L})$ concentrations. In this case, the seedlings germinated in lower concentrations than the one used in the present study $(500 \mathrm{mg} / \mathrm{L})$. However, Locardi (2011) used another type of gibberellic acid in which the propagules were immersed, differing from the methodology used here. Nascimento and Carvalho (2016) kept B. crassifolia seedlings immersed for 24 hours in an aqueous solution of $500 \mathrm{mg} \mathrm{GA3}$ prior to sowing, obtaining about $85 \%$ germination. Probably the propagules of $B$. crassifolia are more lignified than those of $B$. variabilis, which interfered with the absorption of the GA3-containing solution. In addition, while $B$. crassifolia propagules contain three embryos, $B$. variabilis propagules contain only one embryo. This is due to the fact that B. crassifolia fruits are drupe type, whereas $B$. variabilis propagules are samarid (Gates, 1982), which distinguishes these genera (Byrsonima and Banisteriopsis, respectively) in their dispersion process.

Nunes et al. (2006) studied the germination of propagules of Heteropterys byrsonimifolia A.Juss. (Malpighiaceae), whose structures (probably wings) that would allow contamination by pathogens were removed. On the other hand, Hernandez et al. (2011) conducted experiments with Heteropterys tomentosa A.Juss. (Malpighiaceae), in which some of the propagules used had the wings removed, and there were no significant differences in the germination rates in both situations. In the present study, we observed that maintaining the propagule wing favors germination over its removal. Probably, as indicated by Nunes et al. (2006), by maintaining the wings, the propagation of the propagule can be favored, which interferes with its germination.

The $B$. variabilis seedlings are cryptocotyledonous and hypogeal because the cotyledons are enclosed within the seed, in addition to remaining buried (Figure 1C). In this case, the hypocotyl is reduced, and the elevation of the plumule occurs due to epicotyl elevation, unlike what occurs in epigeal seeds, whose growth occurs by hypocotyl elongation, causing elevation of the cotyledons (Appezzato-da-Glória and Carmello-Guerreiro, 2006). Gates (1982) suggests that germination may be a useful character for the definition of subgenus in Banisteriopsis, reporting that preliminary tests indicated that Banisteriopsis subgen. Banisteriopsis C.B.Rob. have epigynous propagules, whereas in Banisteriopsis subgen. Pleiopterys (Nied.) B.Gates and Banisteriopsis subgen. Hemiramma (Griseb.) B.Gates, the propagules are hypogynous. Considering that $B$. variabilis belongs to Banisteriopsis subgen. Hemiramma, the data obtained here reinforce the importance of this character.

Future tests involving substrate and gibberellic acid in the germination of several batches of B. variabilis propagules, as well as other species of Malpighiaceae, are fundamental to encouraging the use of more species of this botanical family in restoration projects of degraded areas.

\section{References}

ANDERSON, W.R., 2013. Origins of Mexican Malpighiaceae. Acta Botánica Mexicana, vol. 104, pp. 107-156. http://dx.doi. org/10.21829/abm104.2013.60.

APPEZZATO-DA-GLÓRIA, B. and CARMELLO-GUERREIRO, S.M., 2006. Anatomia vegetal. 2nd ed. Viçosa: UFV, 438 p.

BARBOSA, L.M., SHIRASUNA, R.T., LIMA, F.C. and ORTIZ, P.R.T., 2015. Lista de espécies indicadas para restauração ecológica para diversas regiões do estado de São Paulo. In: Anais do VI Simpósio de Restauração Ecológica, 6-7 Novembro 2015, São Paulo, Brasil. São Paulo: Instituto de Botânica, pp. 303-436.

BRANCALION, P.H.S., 2013. Experiência com reflorestamentos antigos: obstáculos inesperados e forma de manejo em Floresta 
Estacional Semidecidual. In: Anais do V Simpósio de Restauração Ecológica, 6-8 Novembro 2013, São Paulo, Brasil. São Paulo: Instituto de Botânica, pp. 38-39.

GATES, B., 1982. A monograph of Banisteriopsis and Diplopterys, Malpighiaceae. Flora Neotropica Monographs, vol. 30, pp. 1-237.

HERNANDEZ, F.M.P., COELHO, M.F.B., MAIA, S.S.S. and ALBUQUERQUE, M.C.F., 2011. Germinação de sementes de Heteropteris tomentosa A.Juss. sob diferentes temperaturas e períodos de armazenamento. Agrária, vol. 6, no. 4, pp. 617-621. http://dx.doi.org/10.5039/agraria.v6i4a1336.

JARDIM BOTÂNICO DO RIO DE JANEIRO - JBRJ. Flora do Brasil 2020, 2018 [viewed 25 October 2018]. Malpighiaceae [online]. Rio de Janeiro: JBRJ. Available from: http://floradobrasil. jbrj.gov.br/reflora/floradobrasil/FB155

LOCARDI, B., 2011. Influência da variação sazonal da temperatura e umidade do solo na germinação de sementes de espécies de cerrado: Xylopia aromatica (Lam.) Mart. (Annonaceae),
Banisteriopsis variabilis B. Gates (Malpighiaceae) e Vochysia tucanorum Mart. (Vochysiaceae). Rio Claro: Universidade Estadual Paulista "Júlio de Mesquita Filho", 101 p. Dissertação de Mestrado em Biologia Vegetal.

NASCIMENTO, W.M.O. and CARVALHO, J.E.U., 2016. Propagação do Murucizeiro. In: F.L. GURGEL, ed. O murucizeiro (Byrsonima crassifolia (L.) H.B.K.): avanços no conhecimento e ações de pré-melhoramento. Brasília: Embrapa, pp. 9-25.

NUNES, Y.R.F., FAGUNDES, M., SANTOS, M.R., BRAGA, R.F. and GONZAGA, A.P.D., 2006. Germinação de sementes de Guazuma ulmifolia Lam. (Malvaceae) e Heteropterys byrsonimifolia A.Juss. (Malpighiaceae) sob diferentes tratamentos de escarificação tegumentar. Revista Unimontes Científica, vol. 8, no. 1, pp. 43-52.

QUEIROZ, I.H.B., MENDES, L.F., SEBASTIANI, R. and SAIS, A.C., 2017. The Pirassununga Air Force Farm as a potential area of biodiversity conservation in the Mogi Guaçu River Basin, SP. Holos Environment, suppl., pp. 203-214. 